\title{
Beata Gryko-Andrejuk
}

Wydział Historyczno-Socjologiczny

Uniwersytet w Białymstoku

\section{Typologia obiektów sakralnych fundacji sapieżyńskich w Wielkim Księstwie Litewskim na przełomie XVI i XVII w.}

Sapiehowie, a przede wszystkim Lew Sapieha, dzięki któremu ród stał się jednym z najpotężniejszych na Litwie, znani są nie tylko z działalności politycznej, ale również z licznych fundacji na cele sakralne'. Akty fundacyjne inicjowane przez Sapiehów to nie tylko świątynie, lecz także zgromadzenia zakonne, cerkwie, fundacje mszy świętych, altarie, fundacje szpitali i szkół. Prezentowany artykuł jest jedynie próbą zasygnalizowania szerokiej działalności społecznej Sapiehów, przede wszystkim Lwa i jego najmłodszego syna Kazimierza Leona. Zróżnicowanie typów fundacji świadczy o bogactwie i aktywnej działalności fundacyjnej Sapiehów. W analizie pominięte są kościoły katolickie oraz altarie, które stanowią obiekt osobnego studium.

\section{Klasztory}

Zakony i zakonnicy odgrywali ważną rolę w duszpasterstwie, szkolnictwie (szkoły zakonne) oraz kulturze. Wzrost liczby zakonników, klasztorów nie odbywał się tylko poprzez sprowadzanie nowych zakonów, ale przez rozrastanie się już istniejących. Pierwsza faza wzrostu to lata dwudzieste i trzydzieste XVII w., okres po najostrzejszych walkach pomiędzy katolikami i protestantami. Najpopularniejszymi zakonami byli nadal bernardyni, dominikanie i jezuici. Ponadto od pierwszej połowy XVII w. wzrasta również popularność franciszkanów konwentualnych. Warto postawić w tym miejscu pytanie nie jak doszło do powstania licznych zakonów, ale jak mogły się one utrzymać i funkcjonować?² Nawet naj-

\footnotetext{
1 Kwestie związane z działalnością polityczną porusza A. Czwołak, Piórem i buławą. Działalność polityczna Lwa Sapiehy, kanclerza litewskiego i wojewody wileńskiego, Toruń 2012.

2 Według badań G. Błaszczyka w diecezji wileńskiej powstało do 1569 r. 17 klasztorów męskich i 1 żeński, z których część zniknęła, a dwóch fundacji nie udało się zrealizować; G. Błaszczyk, Litwa na przełomie średniowiecza i nowożytności 1492-1569, Poznań 2002, s. 250.
} 
hojniejsza fundacja była tylko pierwszym punktem zaczepienia dla osiadłej w nim grupy zakonników. Stawało przed nimi wówczas zadanie pełnego zagospodarowania się i wzniesienia kompleksu budynków kościelno-klasztornych. Budowy trwały dziesiątki lat, bardzo często wskutek zniszczeń wojennych, czy pożarów trzeba było podejmować od nowa trud ich odbudowy. Jednocześnie status społeczny klasztorów i zakonników nakazywał utrzymanie życia codziennego i wyposażenia klasztoru na pewnym poziomie. Dotyczyło to nie tylko wyżywienia, ale i na przykład bibliotek. Obok decyzji własnej zakonu i możliwości stworzonych przez fundatora, potrzebna była zgoda biskupa diecezji, na której obszarze miał powstać klasztor. Działalność zakonu musiała być uzgodniona z biskupem, który udzielał zakonnikom między innymi imiennych zezwoleń na spowiedź czy głoszenie kazań. Dla przyszłych fundatorów fundacji zakonnych pojawił się problem. Inicjujący nową fundację musiał się w coraz większej mierze liczyć ze sprzeciwem biskupa i szukać protekcji, czy też innych sposobów przezwyciężenia trudności z inicjatywą fundacyjną. Nie zawsze starania wieńczył pomyślny skutek. Od połowy XVII w. postawa biskupów stanowiła czynnik hamujący proces rozwoju klasztorów. Arbitrem w zatargach kleru świeckiego i zakonnego pozostawała nadal Stolica Apostolska, broniąca zdecydowanie egzempcji zgromadzeń zakonnych i często interweniowała w ich obronie. Główną rolę odgrywała jednak nuncjatura, reprezentująca na miejscu w kraju rzymski punkt widzenia i interesy. Poza protekcją papieską zakony otrzymywały także z Rzymu specjalne przywileje i uprawnienia, ułatwiające im rozwinięcie szerszej działalności. Różnego rodzaju odpusty, pozwolenia na koronację obrazów w kościołach klasztornych, przywileje dla bractw klasztornych podnosiły znaczenie zakonów. Nierzadko zdarzały się zatargi między zakonami i to przede wszystkim na tle zamierzeń fundacyjnych. Zatargi te trwały latami, łączyły się często $\mathrm{z}$ walkami rodzin magnackich. $\mathrm{W}$ momencie najbardziej intensywnego skoku rozwojowego zakonów, jaki miał miejsce w 1635 r., żeby się Polska nie obróciła w kaptańskie królestwo, uchwalono ustawę amortyzacyjną, która wprowadzała zakaz przekazywania Kościołowi jakiegokolwiek majątku stałego ${ }^{3}$.

W tym miejscu należy przejść do czynników, które odegrały najprawdopodobniej decydującą rolę w rozwoju zakonów. Ważne były związki między zakonami a poszczególnymi rodzinami magnackimi. Stosunki te nie ograniczały się tylko do tworzenia fundacji, ale trwały zwykle dalej, odgrywając poważną rolę. Sapiehowie znani byli jako dobroczyńcy i opiekunowie zakonu dominikańskiego. W latach 1580-1648 Sapiehowie ufundowali dwa zakony bernardyńskie i trzy dominikańskie. To sytuuje ich ród na trzecim miejscu spośród fundatorów po Wazach i Potockich ${ }^{4}$. W Wielkim Księstwie Litewskim dzięki hoj-

\footnotetext{
3 J. Mazurkiewicz, Ustawy amortyzacyjne w dawnej Polsce, Lwów 1933, s. 19.

4 Studia nad historia dominikanów w Polsce 1222-1972, pod red. J. Kłoczowskiego, Warszawa 1975, s. 180.
} 
ności rodziny Sapiehów powstały cztery fundacje dominikańskie. Bez wątpienia można nazwać Sapiehów głównymi protektorami zakonu dominikańskiego w Wielkim Księstwie Litewskim w drugiej połowie XVII w. Natomiast jezuici wzbudzali zaufanie zwłaszcza wśród magnaterii swoją zręcznością i wykształceniem. Szczególnie ceniono ich szkolnictwo ${ }^{5}$. W 1594 r. Lew Sapieha ufundował klasztor bernardyński i kościół św. Michała w Wilnie. Zakonnicy sprawowali też bezpośrednią obsługę duszpasterską dworów jako stali kapelani. W $1590 \mathrm{r}$. wykupił w Orszy u miejscowych kalwinistów plac w centrum miasta i nadał jezuitom, którzy zjawili się w mieście w 1604 i 1610 r. ${ }^{6}$ Następnie w 1609 r. przyczynił się do powstania kolegium jezuickiego w Orszy ${ }^{7}$. W 1623 r. wojewoda wileński zadecydował o budowie kolegium jezuickiego w Brześciu Litewskim, wówczas to nadał im majątek Derewnę. Już w roku 1624 r. Lew Sapieha ufundował konwent karmelitów w Białyniczach ${ }^{9}$. Motywem, który skłonił wojewodę wileńskiego do zainicjowania nowego obiektu sakralnego, było zwycięstwo odniesione nad Moskwą w 1618 r. zakończone rozejmem w Dywilinie ${ }^{10}$. Z podobnej inicjatywy powstały również inne akty fundacyjne, m.in. bernardynów grodzieńskich $^{11} .20 \mathrm{~V} 1648$ r. biskup Andrzej Gembicki wydał zezwolenie na sprowadzenie do Berezy kartuzów ${ }^{12}$. Mogli osiąść w dowolnym miejscu w dobrach dziedzicznych Kazimierza Leona Sapiehy ${ }^{13}$. W 1648 r. został położony

5 J. Tazbir, Historia Kościoła katolickiego w Polsce, Warszawa 1966, s. 130.

6 S. Załęski, Jezuici w Polsce, Kraków 1905, t. 4, cz. 3, s. 1055: W samym wirze walki z różnowierstwem w Polsce 1590 r. ksiąze Lew Sapieha kanclerz, w. l. żarliwy katolik a Jezuitów dobrodziej i patron, pragną podźwignać herezją i schizma podupadta sprawę katolickq na Biatejrusi, a zwłaszcza w Orszy, kupit od kalwinów plac, na którym stat ich zbór spalony, czy zburzony, wybudowat na nim kościót i osadzit proboszcza świeckiego księdza Jakóba Laurenty, którego z kolegium papieskiego $z$ Wilna sprowadzit.

7 Ibidem, s. 1055

8 K. Kognowicki, Życie Lwa Sapiehy, Radom 1830, s. 180. S. Załęski, Jezuici w Polsce..., t. 4, cz. 3, s. 1132-1133: ...nadat majętność swoją Derewnę, która kupił od Cywińskich, do tego dodat $1630 \mathrm{r}$. sume 14000 ztp na folwark Ponikwy w województwie brzeskim litewskim zastawny od wojewody podlaskiego Wojciecha Niemiry; dodat i dom na szkoły wartości 1500 złp.

9 Biblioteka Litewskiej Akademii Nauk w Wilnie, F. 273-263 k. 1-8. Inwentarz karmelitów w Białyniczach sporządzony w $1825 \mathrm{r}$.

10 E. Nowakowski, O cudownym obrazie Matki Boskiej w kościele oo. Karmelitów w Białyniczach, Kraków 1899, s. 4.

11 K. Kognowicki, Życie Lwa Sapiehy..., s. 180: kiedy wojsko zwycięskie wedle uchwaty od kopyta końskiego po talaru dawało, Lew Sapieha z hojności swojej dat trzy tysiace.

12 Ibidem, s. 180.

13 Sapiehowie. Materiaty historyczno-genealogiczne i majątkowe, Petersburg 1891, t. 2, s 13: tegoż 1646 r. podkanclerzy Sapieha, starosta Stonimski, wotpiński i lubszański, zeznaje zapis fundacyjny oo. Bernardynom Sapieżyńskim, którym wystawił byt własnym kosztem, w dziedzicznej swej majętności Sapieżyńskiej, inaczej zwanej Drują, kościót i klasztor na górze pewnymi kaplicami ograniczonej... Po gruntownym ukończeniu klasztoru i kościoła podkanclerzy Sapieha potwierdza pierwotny swój zapis funduszowy w trybunale jeszcze w 1643 r. 3 lipca przyznany jeszcze, któ- 
kamień węgielny pod budowę klasztoru i kościoła pod wezwaniem św. Józefa i św. Kazimierza przez nuncjusza apostolskiego Jana de Torresa i fundatora ${ }^{14}$. Fundacja ta została zatwierdzona w 1653 r., a Kazimierz Leon dodał do pierwotnego uposażenia jeszcze dwie wsie ${ }^{15}$. W 1646 r. Kazimierz Leon Sapieha wydał przywilej bernardynom na założenie w Drui klasztoru bernardyńskiego i kościoła pod wezwaniem św. Trójcy ${ }^{16}$. Ponadto Kazimierz Leon sprowadził w 1649 r. do Nowogródka bonifratrów, którzy otrzymali fundusz składający się z czynszów z 8 domów w mieście i niedużego ośmiomorgowego folwarku ${ }^{17}$. Jan Stanisław Sapieha w 1650 r. ufundował w Słonimiu murowany kościół dla kanoników laterańskich, zapisał na jego uposażenie majątek Darew ${ }^{18}$. Przyczynił się do powiększenia fundacji kościoła i klasztoru franciszkanów w Słonimiu, przekazując na ten cel znaczne sumy ${ }^{19}$.

Mówiąc o klasztorach, nie należy zapominać o prawosławnych monasterach i cerkwiach, które w istotny sposób wpływały na religijność i obyczaje całej Rzeczypospolitej. Monastery stanowiły ośrodki życia kontemplacyjnego i centra duchowne. Jeden z najbardziej znanych i cenionych monasterów powstał na początku XVI w. w Supraślu dzięki fundacji Chodkiewiczów. W państwie Jagiellonów Cerkiew prawosławna była tolerowana i otaczana opieką panujących ${ }^{20}$.

rym na wyżywienie i prowizja oo. Bernardynów wyznaczył corocznq ordynację, zwana jałmużna, z dziesięcin swych majątków Ikaźni, Dombrowicy i Oświeja; J. Żmigrodzki, Nowogródek i okolice, Nowogródek 1931, s. 37; H. Lulewicz, Jan Stanisław Sapieha, Polski Słownik Biograficzny, t. 34, z. 143 , s. 628 .

14 Ibidem, s. 3.

15 Fundacja oyców kartuzów w Berezie, [w:] Volumina Legum, wyd. J. Ohryzko, Petersburg 1860, t. 5, s. 89: Lubo fundacja pomienionych Oyców kartuzów przez. Wiel: niegdy Kazimierza Leona Sapiehę aucta et dotata konstytucją anni 1653 iest aprobowana. Że jednak Wielmożny Podkanclerzy po zasztej konstytucji dla lepszej wygody pomienionych Oyców dwie wioski nabywszy przydat, tedy one do tejze fundacji pomienionym Oycom inkorporujemy, y moca tego Sejmu stwierdzamy (salvis oneribus Reipublicae) reassumuiąc konstytucja anni 1667 klasztorom wszystkim w Koronie y w W. X. Lit. stużąca.

16 Sapiehowie. Materiaty..., t. 2, s. 13: tegoż 1646 r. podkanclerzy Sapieha, starosta Słonimski, wotpiński i lubszański, zeznaje zapis fundacyjny oo. Bernardynom Sapieżyńskim, którym wystawit byt własnym kosztem, w dziedzicznej swej majętności Sapieżyńskiej, inaczej zwanej Druja, kościót i klasztor na górze pewnymi kaplicami ograniczonej... Po gruntownym ukończeniu klasztoru $i$ kościoła podkanclerzy Sapieha potwierdza pierwotny swój zapis funduszowy w trybunale jeszcze w 1643 r. 3 lipca przyznany jeszcze, którym na wyżywienie i prowizjq oo. Bernardynów wyznaczyt corocznq ordynację, zwana jałmużna, z dziesięcin swych majątków Ikaźni, Dombrowicy i Oświeja.

17 J. Żmigrodzki, op. cit., s. 37.

18 H. Lulewicz, op. cit., s. 628.

19 Ibidem, 628.

20 Panujące powszechnie twierdzenie o zakazie budowy i naprawie starych cerkwi w Wielkim Księstwie Litewskim (akt wydany rzekomo przez Kazimierza Jagiellończyka, późniejszego świętego w 1480 r.), faktycznie nie miał miejsca. Podobnie, jak zakaz piastowania niektórych urzędów (wojewody oraz kasztelana wileńskiego i trockiego) nie był przestrzegany, o czym świadczy ka- 
Po unii brzeskiej Kościół unicki staje się uprzywilejowany, głównie przez gwarancje i przywileje Zygmunta III. Unici mogli liczyć na pomoc i przychylność magnatów. Rolę kulturotwórczą w Kościele unickim pełnił zakon bazylianów, który przejął od jezuitów aktywne życie połączone z praktyką ascezy. W dużej mierze fundatorami unickich obiektów sakralnych byli katolicy, którzy dbali o pobożność i możliwość praktykowania kultu przez swych poddanych. Stanowić to mogło również pewnego rodzaju odrębność magnaterii Wielkiego Księstwa Litewskiego, chcącej podkreślić swoją pozycję wobec magnaterii Korony.

\section{Cerkwie prawosławne, cerkwie unickie}

W Wielkim Księstwie Litewskim Cerkiew prawosławna nie posiadała większych praw, ale była tolerowana przez Jagiellonów. Po zawarciu unii brzeskiej wszystkie prawa i przywileje zostały przelane na Kościół unicki. Przy Cerkwi prawosławnej pozostały tylko dwie diecezje Kościoła wschodniego: przemyska i lwowska ${ }^{21}$. Powszechnie znany zakaz naprawy starych i budowy nowych cerkwi, rzekomo wprowadzony z inicjatywy królewicza Kazimierza Jagiellończyka, nie był przestrzegany. Według G. Błaszczyka zakaz ten obowiązywał jedynie na terytorium Litwy etnicznej i przylegających terenów ${ }^{22}$. Po wprowadzeniu postanowień unijnych, wbrew oczekiwaniom, przy prawosławiu pozostały Bractwa i niektóre klasztory z Ławrą Pieczerską na czele, a także część mieszczaństwa, duchowieństwa i szlachty, przede wszystkim zaś protektor prawosławia w Wielkim Księstwie Litewskim, książę Konstanty Wasyl Ostrogski²3. Szczególną datą w historii Cerkwi prawosławnej w Rzeczypospolitej jest rok 1620, kiedy patriarcha jerozolimski, Teofanes wznowił prawosławną hierarchię i mianował metropolitą Hioba Boreckiego ${ }^{24}$. Akt ten był bezprawny, ponieważ to królowi Zygmuntowi III przysługiwało prawo nominacji biskupów. Dopiero Władysław IV w 1632 r. uznał hierarchię prawosławną, jednocześnie mianując metropolitą kijowskim Piotra Mohyłę. Trzy lata później zezwolił na utworzenia Akademii Mohylańskiej w Kijowie ${ }^{25}$.

riera Konstantego Ostrogskiego, który w 1514 r. otrzymał nominację na kasztelanię wileńską, a w 1522 r. król Zygmunt Stary nadał mu województwo trockie; por. W. Kamieniecki, Ograniczenia wyznaniowe w prawodawstwie litewskim w XV i XVI w., „Przegląd Historyczny” 1911, t. 13, z. 3 .

21 B. Kumor, Historia Kościoła, cz. 5 czasy nowożytne. Rozłam w chrześcijaństwie zachodnim, Lublin 1984, s. 247.

22 G. Błaszczyk, op. cit., s. 255.

23 B. Kumor, op. cit., s. 247.

24 Ibidem, s. 247.

25 Ibidem, s. 247. 
Kościół prawosławny w Wielkim Księstwie Litewskim posiadał odrębny podział administracyjny, który został ustalony w $1458 \mathrm{r}$. i dzielił się na dwie metropolie - kijowską i moskiewską ${ }^{26}$. Metropolia kijowska (kijowsko-halicka) dzieliła się na dziesięć eparchii (biskupstw): metropolitalna kijowska, połocka, smoleńska, czernihowska, turowska (pińska), łucka, włodzimierska, chełmska, przemyska i halicka ${ }^{27}$. Centralne organy władzy należały do metropolitów, eparchów, a także do synodów prowincjonalnych i kryłosów, czyli organów władzy administracyjnej i sadowej przy eparchiach ${ }^{28}$. W organizacji terytorialnej można wyróżnić protopopie (namiestnictwa), które były odpowiednikiem dekanatów w Kościele katolickim i parafie (parochie) ${ }^{29}$. Podobnie jak Kościół katolicki, Cerkiew prawosławna prowadziła działalność duszpasterską, oświatową i charytatywną, jednak w mniejszym stopniu. Szkolnictwo stało na bardzo niskim poziomie, co znalazło odzwierciedlenie w stanie wykształcenia duchowieństwa.

Po zawarciu unii brzeskiej nowy Kościół unicki potrzebował protektorów, którzy dbaliby o jego interesy zarówno na dworze królewskim, na sejmie, sejmikach czy w sądach. Jednym z protektorów unii, który udzielał Kościołowi unickiemu poparcia był Lew Sapieha. Było on jednym z przywódców stronnictwa regalistycznego na Litwie, jak również był silnie zaangażowany w działalność kontrreformacyjną Kościoła rzymskokatolickiego. Jego działania na rzecz unii to także liczne fundacje na rzecz Kościoła unickiego. Tuż po zawarciu unii wszystkie cerkwie i monastery znajdujące się w jego dobrach przeszły pod jurysdykcję biskupów unickich. Ponadto był on fundatorem cerkwi w Siemiatyczach, Różanie, Witorożu, Mińsku, Tołoczynie, a także przyczynił się do uposażenia cerkwi w Wilnie, Trokach, Mścisławiu, Żyrowicach ${ }^{30}$. Lew Sapieha finansował również druk książek religijnych, liturgicznych na potrzeby Kościoła unickiego ${ }^{31}$. Fundując cerkiew w Witorożu w 1605 r., Lew Sapieha motywował to potrzebą rozmnożenia chwały Pana Boga Wszechmogącego, jednocześnie zobowiązał on duchownych do posłuszeństwa biskupom brzeskim, którzy opowiedzieli się po stronie unii ${ }^{32}$. O jego zaangażowaniu na rzecz unii może również świadczyć zapis sporządzony w pozostawionym testamencie, w którym wyraża, aby nadania dla cerkwi pozostawały niezmienione ${ }^{33}$. Sapiehowie, a zwłaszcza Lew Sapieha,

\footnotetext{
26 G. Błaszczyk, op. cit., s. 257.

27 Ibidem, s. 258.

28 Ibidem, s. 258.

29 Ibidem, s. 259.

30 Akty otnosjaščesja k istorii zapadnij Rossii sobrannye i izdavaemye Archeografičeskoju Kommissieju, Sankt Petersburg 1851, t. 4, nr 136, s. 189-191.

31 T. Iljaszewicz, Drukarnia domu Mamoniczów w Wilnie (1575-1622), Wilno 1938, s. 77-78.

32 Akty izdavaemye Wilenskoju Archeografičeskoju Kommissieju dla razbora drevnich aktov $w$ Wilnie, Wilno 1870 , t. 3, s. 20-23.

33 Sapiehowie. Materiaty historyczno-genealogiczne i majątkowe, Petersburg 1890, t. 1, s. 182.
} 
osobiście propagowali kult biskupa unickiego Jozafata Kuncewicza, któremu Kazimierz Leon Sapieha w 1645 r. ufundował srebrny sarkofag ${ }^{34}$. Lew Sapieha, wojewoda wileński w 1623 r. ufundował cerkiew Dowieczorowską pod wezwaniem Przeczystej Bogarodzicy Maryi. Nowa cerkiew przeznaczona została dla ludności wyznania unickiego. Fundator wyposażył również wnętrze świątyni, a także wyznaczył duchownego ${ }^{35}$.

\section{Fundacje mszalne}

Szczególne znaczenie i miejsce w życiu i działalności magnaterii Wielkiego Księstwa Litewskiego, w tym także Sapiehów odgrywały fundacje mszalne. Jednym $\mathrm{z}$ podstawowych zagadnień egzystencjalnych $\mathrm{w}$ życiu człowieka niemal od początku świata była śmierć. W różnych epokach historycznych i kręgach cywilizacyjnych śmierć była inaczej przedstawiana, co stawało się wyznacznikiem określającym kulturę, mentalność. Obecnie problematyka śmierci pojawia się w wielu dziedzinach nauki ${ }^{36}$. Nauka chrześcijańska zalecała przygotowywanie się przez całe życie do odejścia z doczesnego świata. Środkiem, który miał wspomagać przygotowania do śmierci, była literatura dewocyjna, a przede wszystkim podręczniki dobrego umierania (ars bene moriendi), w których zalecano jak najlepiej przygotować się do śmierci, aby pozbyć się niepożądanych konsekwencji po zgonie, czyli długiego pobytu w czyśćcu lub wiecznych mąk piekielnych. Podręczniki dobrego umierania zalecały podporządkowanie życia rozważaniom tajemnicy śmierci, co miało powoli przyzwyczaić człowieka do myśli o śmierci ${ }^{37}$. Wskazywały również na konieczność uporządkowania rzeczy doczesnych, sporządzenia testamentu. Jednak mimo wszystko bardziej dbano o sferę duchową,

34 P. Krasny, Relikwiarz św. Jozafata Kuncewicza w katedrze połockiej. Przyczynek do badań nad srebrnymi trumnami relikwiarzowymi w Rzeczypospolitej w XVII w., [w:] Studia nad sztukg renesansu i baroku, t. 4, red. J. Lileyko, Lublin 2000, s. 122.

35 Akty izdavaemye Wilenskoju Archeografičeskoju Kommissieju dla razbora drevnich aktov, Wilno 1908, t. 33, s. 221.

36 J. Salej, Czy śmierć jest karq za grzechy?, [w:] Sens choroby, sens śmierci, sens życia, Kraków 1984; M. Vovelle, śmierć w cywilizacji Zachodu. Od roku 1300 po wspótczesność, Warszawa 2004; T. Chrzanowski, Wędrówki po Sarmacji Europejskiej, Kraków 1988; S Herman, Śmierć Sarmaty na polu bitwy, „Teksty” 1979, nr 3; J. Ekes, Sarmacka świadomość życia i śmierci, [w:] Odrodzenia i Reformacja w Polsce, Wrocław-Warszawa-Kraków-Gdańsk 1971, t. 16; J. Delumeau, Grzech i strach. Poczucie winy w kulturze Zachodu XIII-XVIII w., Warszawa 1994; Ph. Aries, Człowiek i śmierć, Warszawa 1992; M. Włodarski, Ars moriendi, Kraków 1978; B. Rok, Człowiek wobec śmierci w kulturze staropolskiej, Wrocław 1995; W. Czapliński, J. Długosz, Życie codzienne magnaterii polskiej w XVII w., Warszawa 1976.

37 B. Rok, Zagadnienie śmierci w czasach nowożytnych - próba postawienia problematyki badawczej i charakterystyka źródeł, „Medycyna Nowożytna. Studia z medycyny nowożytnej”, 1994, t. 1 , z. 1 , s. $23-45$. 
a w mniejszym stopniu o materialną, związane to było z wizją życia po śmierci głoszoną przez Kościół. Duchowni w kazaniach głosili cudowny obraz życia w niebie, jak i wiecznego potępienia w piekle lub czyśćcu. Moment śmierci był również wykorzystywany do bardziej praktycznych celów, stanowił wspaniałą okazję do zapoczątkowania licznych fundacji zarówno sakralnych, jak i mszalnych. Fundacje mszalne były dokonywane przez umierającego lub członków jego rodziny, miały one za zadanie wyjednanie zbawienia. Początek zamawiania mszy za dusze zmarłych wiąże się z doktryną czyśćca, jako miejsca przejściowego, w którym miała przebywać dusza po śmierci, zanim zostanie oczyszczona z grzechów ${ }^{38}$. Po raz pierwszy czyściec określił papież Grzegorz I w 593 r., a zgodnie z uchwałami Soboru Florenckiego stał się on dogmatem ${ }^{39}$. Zwyczaj fundowania mszy świętych za zmarłych był niezwykle popularny w średniowieczu i w okresie nowożytnym, właściwie nigdy całkowicie nie zanikł. W Rzeczypospolitej zamawianie mszy świętych $\mathrm{w}$ intencji zmarłych było szczególnie popularne w XVII-XVIII w., wiązało się to aktywnością Kościoła katolickiego ${ }^{40}$. Podczas badania fundacji magnackich nasuwają się pytania, czy sam akt fundacji mszalnych należy wiązać tylko i wyłącznie z pobożnością fundatora oraz obawą przez mękami piekielnymi, czy może chodziło również o motywy prestiżu?

Sapiehowie, podobne jak i większość rodzin magnackich w Rzeczypospolitej w każdy możliwy sposób starali się zapewnić sobie możliwie największą ilość modlitw po śmierci, co miało uchronić ich dusze od wiecznego potępienia, odpuszczenia grzechów w chwili śmierci, a także szczęście i zdrowie w życiu doczesnym $^{41}$. Najwięcej informacji o zamawianiu mszy za zmarłych można odnaleźć w aktach fundacyjnych zgromadzeń zakonnych, świątyń, a także w testamentach. Podobnie jak akty fundacyjne, testamenty stanowią doskonałą bazę źródłową do poznania kultury duchowej i materialnej społeczeństwa w XVI-XVIII w., zawierają oprócz typowych formuł wyznania wiary również informacje dotyczące pogrzebu. W nich to zazwyczaj odnajdujemy fundacje mszalne. Nierzadkim przypadkiem jest również odmawianie modlitwy czy odprawiania nabożeństw przez zgromadzenia zakonne w zamian lub w podzięce za wsparcie. Było to swego rodzaju zapłatą za wszelkie dobra otrzymane od fundatora. W przypadku śmierci fundatora lub członka jego rodziny zobowiązanie odprawienia określonej liczby nabożeństw spoczywało zazwyczaj na wyższych dostojnikach kościelnych, biskupach, ordynariuszach, przełożonych klasztorów, którzy to z kolei zlecali to

38 E. Przybył, Czyściec, [w:] Religia, Encyklopedia PWN, t. II, s. 125-127.

39 The Catholic Encyklopedia, red. R. Beoderick, Nashville 1987, s. 502.

40 J. Tazbir, Religijność szlachecka, [w:] Kultura szlachecka w Polsce, Poznań 2002, s. 106-132; Kościót w Polsce, t. II wiek XVI-XVIII, pod red. J. Kłoczowskiego, Kraków 1969.

41 Problem fundacji mszalnych na przykładzie Radziwiłłów nieświeskich porusza K. Stojek-Sawicka, Pro remdio animae. Fundacje mszalne Radziwiłtów nieświeskich w XVIII w., „Przegląd Historyczny" 2008, t. XCIX, z. 23, s. 411-427. 
podległemu duchowieństwu. Obowiązek sprawowania modlitw w intencji fundatora $\mathrm{i}$ jego rodziny w dużej mierze spoczywał na zgromadzeniach zakonnych fundowanych przez Sapiehów, które znajdowały się w ich dobrach. Kazimierz Leon Sapieha ustanawiając fundację w Berezie Kartuskiej, zobowiązał zakonników do odprawiania nabożeństw za dusze jego żony, ojca, matki i dwóch braci ${ }^{42}$. Szczególnie predestynowane do modlitw w intencjach fundatorów i członków rodzin były zgromadzenia zakonne żeńskie. Jedną z ich funkcji było wstawiennictwo w wyjednywaniu rozmaitych dobrodziejstw dla ciała i ducha fundatorów ${ }^{43}$. Lew Sapieha, czyniąc fundację klasztoru i kościoła pod wezwaniem św. Michała w Wilnie w 1594 r. jednocześnie zobligował zakonnice do nieustannych modlitw za Najjaśniejszego Króla Pana Miłościwego i za wszystek senat Korony Polskiej $i$ Wielkiego Księstwa Litewskiego oraz za cała Rzeczypospolitq ${ }^{44}$. Duchowieństwo katolickie zachęcało do ograniczenia wydatków na pogrzeb, a cynowy sarkofag, portret trumienny, chorągwie nagrobne, katafalk czy wystawne uczty uważane były za zbędny wydatek. Sugerowano jednocześnie wydawanie pieniędzy na msze za zmarłych, za dusze znajdujące się w czyśćcu. Jakub Wujek pisał, że należy w intencji dusz zmarłych odprawiać ofiary mszey modlitwy, jałmużny, posty, obchody, wigilie y insze dobre uczynki ${ }^{45}$. Lew Sapieha w sporządzonym w $1633 \mathrm{r}$. testamencie zobowiązuje swoich potomków, aby modlitwami i jałmużną wspierali jego grzeszną duszę, jednocześnie prosi o możliwie największą liczbę mszy świętych $^{46}$. Natomiast Kazimierz Leon Sapieha, w testamencie sporządzonym 30 lipca 1655 r. przeznaczył 28000 złotych czerwonych na odprawienie mszy świętych ${ }^{47}$. Sapiehowie czyniąc akt fundacyjny, jednocześnie zobowiązywali kapłanów do wynoszenia modlitw w ich intencjach za życia i po śmierci, dotyczyło to zarówno fundacji obiektów sakralnych katolickich, jak i obrządków wschodnich. Mikołaj Sapieha wojewoda witebski, czyniąc fundację cerkwi w Kodniu w 1625 r., zobligował kapłana do modlitw za dusze zmarłych przodków ${ }^{48}$. W 1629 r. Mikołaj

\footnotetext{
42 Sapiehowie. Materiaty..., t. 2, s. 39

43 M. Borkowska, Panny siostry $w$ roli instytucji ustugowej. Czego oczekiwało społeczeństwo od klasztoru żeńskiego w XVII-XVIII w., [w:] Klasztory w społeczeństwie średniowiecznym i nowożytnym, red. M. Derwich, A. Pobóg-Lenartowicz, Opole-Wrocław 1996, s. 55-63.

44 K. Kognowicki, op. cit., s. 178.

45 J. Chrościcki, Pompa funebris, Warszawa 1974, s. 57.

46 Sapiehowie. Materiaty..., t. 1, s. 400, 407: potomków moich proszę aby mię $w$ tey potrzebie zbawiennej po śmierci mej wspomogli i ratowali, dusze moja modlitwami, jałmużnami, jako Pan Bóg do serca ich poda, i jako chęć i miłość ich ku mnie i sity mogq. Osobliwie o to proszę aby mszy święte, jako najszęściey tricesimy, aniwersarij $i$ wszystko to co kościót święty Katolicki Rzymski za dusze zmartych ludzi czynić radzi i przykazuje, jako najpilniej czynili, odprawowali i wypetniali.

47 Testament Kazimierza Leona Sapiehy, podkanclerzego Wielkiego Księstwa Litewskiego, [w:] Sapiehowie. Materiaty..., t. 2, s. 245-259.

48 Akty izdawajemyje wielnskoju archeograficeskoju kommisjeju..., t. 3, s. 29: za dusze zmartych przodków moich Pana Boga prosić, tudziesz y za dobre zdrowie mie y mitey matżonki Moyey y dziatek moich.
} 
Sapieha wraz z żoną Anna Wojnianką położyli fundament pod nową świątynię p.w. św. Anny, jednocześnie wyznaczając obowiązki religijne celebrowania mszy świętych, w każdy dzień tygodnia poświęconą innej intencji: w poniedziałki za duszę Aleksandra Sapiehy podkanclerzego litewskiego, we środy i czwartki za odpuszczenie grzechów fundatora i jego rodziny ${ }^{49}$. Lew Sapieha w 1593 r. dając początek kościołowi w Ikaźni, zobowiązał plebana do modlitw za dusze przodków oraz we własnej intencji za przebaczenie grzechów ${ }^{50}$. W podobny sposób wraz z aktem fundacyjnym świątyni w Różanej, w 1626 r. z inicjatywy Lwa Sapiehy, powstała fundacja modlitw śpiewanych ${ }^{51}$. Lew Sapieha wraz z aktem fundacyjnym świątyni w Horach w $1626 \mathrm{r}$. wyznaczył określone modlitwy do każdego tygodnia in perpetuum ferijs quqrtis, et sextis inszych pro peccatis animae mea et successorum metrum odprawować powinni będq ${ }^{52}$. Sapiehowie dokonując fundacji mszalnych, starali się ograniczać je czasowo. Zazwyczaj msze były odprawiane dwa razy w tygodniu. Były to nabożeństwa żałobne, które zawierały nieco inne treści, dostosowane do okoliczności życia i śmierci, w intencji których je sprawowano. Fundatorzy określali, jakie msze miały być sprawowane: prywatne bez udziału wiernych i bez uprzedniej zapowiedzi (missa privata), czy też msze śpiewane połączone $\mathrm{z}$ czuwaniem ${ }^{53}$. Msze zamawiano z góry i opłacano jednorazowo lub ze specjalnego funduszu mszalnego, który był zazwyczaj lokowany na dobrach ziemskich, a jego wysokość zależała od liczby zamówionych nabożeństw. Halszka Radziwiłłówna na obrzędy do zbawiania potrzebne przeznaczyła sumę $1500 \mathrm{złp}^{54}$. Fundacje mszalne cieszyły się dużą popularnością wśród magnatów, ich ilość i miejsce, w którym były sprawowane świadczyły o bogactwie, potędze i pozycji rodu. Na tym etapie badań nie można stwierdzić, czy fundacje mszy świętych były trwałe, czy potomkowie dbali o kontynuowanie pierwotnych fundacji mszalnych swoich przodków. Niezależnie od pierwotnych motywów, fundacje mszalne były świadectwem pobożności magnaterii, a zbiorowe modlitwy miały pomóc w wyjednaniu zbawienia, jednocześnie łagodziły poczucie strachu w obliczu śmierci.

\footnotetext{
49 J. Pruszkowski, Kodeń Sapiehów, Kraków 1898, s. 26-27.

50 Biblioteka Czartoryskich [dalej B. Czart.] 1777, s. 585, Fundusz Leona Sapiehy, 16 lipca 1593, Ikaźnia: pleban ikaźnieński teraźniejszy i na potem będący za dusze umartych przodków moich, tudzież aby Pan Bóg grzechom moim byt mitościwym ofiare w pomienionych kościołach ofiarować, $i$ insze obrzędy kościoła chrześcijańskiego wypetniać będzie sam $w$ kościele jednym, a $w$ drugim przez wikarego, aby nigdy nie ustawała służba.

51 B. Czart. 1777, s. 915, Fundacja Lwa Sapiehy w Różanej, 2 października 1626: oficjum o Krzyżu Świętym, w którym się krótko wszystka męka i śmierć Pana i Zbawiciela naszego Chrystusa Jezusa rozpamiętywana na każdy dzień, w każdy miesiąc, kwartat, rok od roku wiecznymi czasy przede msza święta śpiewano byto.

52 Ibidem, s. 941, Fundacja Lwa Sapiehy w Horach 1626.

53 S. Koperek, Udział świeckich w liturgii Godzin, [w:] Misteriu Christi, t. 2, s. 191-208.

54 Sapiehowie. Materiaty..., t. 1, s. 395.
} 


\section{Szpitale}

Przejawem fundacyjnej działalności Sapiehów były również fundowane zazwyczaj wraz z kościołem szpitale (przytułki). Czy ta inicjatywa była jedynie przejawem miłosierdzia? Temat ten posiada dość dużą literaturę ${ }^{55}$. W czasach nowożytnych terminem szpital określano instytucję, która była w zasadzie przytułkiem dla ubogich i chorych, dzieci-podrzutków i ogólnie dla osób potrzebujących pomocy. Tylko nieliczne z nich zajmowały się leczeniem chorych ${ }^{56}$. Charytatywna i oświatowa działalność Kościoła realizowana była zarówno na polu oświaty, jak i szpitalnictwa, które do końca XVIII wieku pozostawały pod jurysdykcją kościelną. Pierwsze informacje o zakładaniu szpitali w Polsce pochodzą z okresu panowania Bogusława Krzywoustego. Wówczas to jednym z głównych zadań szpitala i zakonów, przy których funkcjonowały szpitale, było szerzenie chrystianizacji oraz udzielanie opieki potrzebującym ${ }^{57}$. Prowadzeniem szpitali zajmowali się dominikanie, franciszkanie, augustianie, cystersi czy joannici. Szpitale stanowiły rodzaj czynnika pobudzającego do dalszych nadań na rzecz klasztorów. Funkcja lecznicza nadal pozostawała na dalszym planie, zazwyczaj ograniczano się do udzielania schronienia, zapewne bez wyżywienia, wyjątek mogli stanowić obłożnie chorzy. Szpitale należące do miast służyły podróżującym. Powstawały, więc głównie przy drogach handlowych, miały one pełnić funkcję pomocową osobom obcym, przybyszom, a także stanowić barierę przed epidemią dla miasta.

Sapiehowie są dotychczas znani z licznych fundacji obiektów sakralnych, jednak przy wielu kościołach zakładano także przytułki. W tym miejscu warto zastanowić się nad kilkami kwestiami. Co skłaniało możnych do zapoczątkowania właśnie takiej formy aktów miłosierdzia? Czy były to postanowienia Soboru Trydenckiego? Czy wiązało się to z inwestycją w życie wieczne? A może była to forma dziękczynienia? Czy troska o podniesienie poziomu katechizacji? Czy było to podyktowane względami humanitarnymi? Warto również zastanowić się nad okolicznościami powstania szpitali, czy pojawiały się w czasie klęsk elementarnych?

O formach wielu aktów miłosierdzia zadecydowały zapewne postanowienia Soboru Trydenckiego, ponieważ już w 1593 r. Lew Sapieha, inicjując fundusz

55 M. Sudracki, Opieka społeczna w Wielkopolsce Zachodnie w XVII i XVIII w., Lublin 1992; Z. Guldon, W. Kowalski, Szpitale $w$ województwie sandomierskim $w$ drugiej połowie XVII w., „Nasza Przeszłość” 1995, t. 84; M. Słoń, Szpitale lwowskie w wiekach średnich, „Przegląd Historyczny” 1994, t. 85; D. Prucnal, Stan badań nad szpitalnictwem w przedrozbiorowej Polsce, „Roczniki Humanistyczne” 46 (1999), z. 2; F. Giedryć, Zapiski do dziejów szpitalnictwa w dawnej Polsce, Warszawa 1908; K. Dola, Szpitale w średniowiecznej Polsce pod zarzadem kościelnym, [w:] Studia i Materiaty, Rzym 1972.

56 K. Dola, Opieka społeczna Kościoła, [w:] Historia Kościoła, red. B. Kumor, Z. Obertyński, Poznań-Warszawa 1974, t. 1, s. 166-175.

57 Z. Podgórska-Klawe, Od hospicjum do wspótczesnego szpitala, Wrocław 1981, s. 27. 
kościoła w Ikaźni, nie zapomina o szkole i szpitalu, nadając im grunty ${ }^{58}$. Kolejne fundacje powstały w 1604 r. w Czerei, Leplach, Tołoczynie i Starosielu. Lew Sapieha fundując kościół w Czerei, wyznaczył place na plebanię, szkołę i szpital59. Podobne uposażenie otrzymała fundacja, w Leplach w województwie połockim. Sapieha zapisał jednocześnie place, dom i ogrody na plebanię, szkołę i szpital, dał możliwość połowu ryb z jeziora Bobryce ${ }^{60}$. Również w 1604 r. powstał kościół wraz ze szkołą i szpitalem w Starosielu ${ }^{61}$ oraz w Tołoczynie ${ }^{62}$. W 1608 r. Zygmunt III potwierdził fundację Lwa Sapiehy w mieście Słonim, argumentując to koniecznością pomnożenia chwały bożej i zbawieniem dusz ${ }^{63}$. W $1614 \mathrm{r}$. Lew Sapieha uposażył ufundowany wcześniej szpital w miasteczku Różana w diecezji wileńskiej, który był przeznaczony dla 16 ubogich $^{64}$. W 1624 r. Lew Sapieha potwierdził wcześniejszy zapis Konstantego Ostrogskiego, wojewody kijowskiego na szpital zdzięciolski ${ }^{65}$. Kolejna fundacja szpitalna z inicjatywy Lwa Sapiehy powstała w 1626 r. w Horach ${ }^{66}$. Ważny jest również czas powstania szpitali: w 1593 r. jeden, w 1604 r. powstało ich aż cztery. W tym czasie Lew Sapieha

58 B. Czart. 1777, s. 585-589, Fundusz Leona Sapiehy, 16 lipca 1593, Ikaźnia... a na mieszkanie plebanowi, $i$ inszej księżej, także na szkote $i$ szpital, y poddanych grunt ten wszystek, który jest podle tego kościoła, między droga Druyska bokiem do ptota, przy tejże drodze leżacej, bokiem do drogi, które idzie do morgów miejskich z miasteczka, podle tegoż kościoła, uliczna z rynku do wrót miejskich, ze wszystkimi poddanymi, mieszczany i ich powinnościami, domami, ogrody, służa, czynszami i kapszczyna piwna, i inszemi pożytkami, któregokolwiek $w$ tym opisanym placu sa, i potym wynalezione być moga.

59 Ibidem, s. 679-68, Fundacja Lwa Sapiehy w Czerei, potwierdzona przez Zygmunta III, 6 sierpnia 1604.

60 Ibidem, s. 682, Fundacja Lwa Sapiehy w Leplach z 1604 roku potwierdzona przez Zygmunta III w roku 1606.

61 Ibidem, s. 691-695.

${ }^{62}$ Ibidem, s. 695, Potwierdzenie przez Zygmunta III fundacji Tołoczyna dokonanej przez Lwa Sapiehę.

63 Ibidem, s. 726-729, Potwierdzenie przez Zygmunta III fundacji kościoła w Słoninie uczynionej przez Lwa Sapiehę, 5 lipca 1608 r.

${ }^{64}$ Biblioteka Uniwersytetu Wileńskiego, Dział rękopisów, F.57, B53.40, AV z 1633r., k. 86-86v. memu różanskiemu i innym urzędnikom po tym będacym, isz dawne jest postanowienie przodków moich [że] do szpitala różańskiego ze mtynów mych różańskich po beczce żyta na miesiąc daja, a jam rozkazał dawać z folwarku po drugiej beczce $i$ ta na chleb, i po beczce stodu na piwo, albo na kwas, do tego na rok grochu beczki 2, jęczmienia na krupy beczek 10, tatarki beczek 1, stoniny połci 6, sadet 3, soli beczek 2, a teraz na post kupcie im beczkę śledzi koniecznie, co sobie za tym listem a kwitami księdza plebana różańskiego będzie na liczbie przyjęto. Obmyślit tesz im ogród jaki na warzywo, a zapomóg ich, aby sobie mogli posiać konopi, maku, rzepy, marchwie, pasternaku, ćwikły i kapusty zasadzić. Datum ze Stonima die 16 Februarii Anno 1614. I teraz daj im co warzywa jakiego.

65 B. Czart. 1777, s. 922, Uposażenie Leona Sapiehy dotyczącej fundacji w Zdzięciole, 11 octobris $1624 \mathrm{r}$.

66 Ibidem, s. 937-941, Fundacja Leona Sapiehy w Horach, 1626 r. 
sprawował godność kanclerza wielkiego litewskiego (od 1589 r.). Jednocześnie był to okres wprowadzania w życie reformy katolickiej, a kanclerz, jako konwertyta gorąco zaangażował się w sprawy swojego nowego wyznania. Kolejne szpitale powstały w 1624 r. w Zdzięciole i Kossowie, w 1626 r. w Horach, co zbiega się w czasie z kolejną falą ,powietrza morowego", która nadeszła z Turcji lub Węgier i zaatakowała ziemie polskie około roku 1622.

Na podstawie dostępnych mi źródeł trudno jest uchwycić rzeczywiste uposażenie szpitali, ponieważ znaczna ich część nie miała stałych dochodów. Uposażenie w postaci ziemi uprawnej najczęściej posiadały szpitale miejskie, ale bardzo często zdarzało się, że ziemia szpitalna była dzierżawiona, co pomniejszało jej dochody ${ }^{67}$. W sytuacji, gdy szpital nie posiadał dochodów z gruntów, magnaci-fundatorzy zapisywali na jego rzecz stałe zaopatrzenie w żywność i inne niezbędne rzeczy ${ }^{68}$. Na ogół szpitale dawały jedynie dach nad głową, a o resztę ich mieszkańcy musieli sami się zatroszczyć. Ziemia i dochody stawały się własnością Kościoła prawem wieczystym.

Syn Lwa Sapiehy, Kazimierz Leon w 1649 r. wraz z fundacją klasztoru bonifratrów, wyznaczył fundusz na szpital dla 10 ubogich w Nowogródku ${ }^{69}$. Franciszek Stefan Sapieha, koniuszy litewski, który w latach 1671 i 1685 potwierdził i powiększył fundusz cerkwi św. Spasa w Trościenicy, w testamencie z 8 września 1683 r. zapisał dom w Boćkach z rentą roczną na szpital dla ubogich, drugi szpital uposażył w Lachowiczach ${ }^{70}$.

Mieszkańcy szpitala $\mathrm{w}$ zamian za pobyt $\mathrm{w}$ szpitalu byli zobowiązani do prac na rzecz kościoła, kleru i szpitala, zdarzało się, że pensjonariusze musieli sami zadbać o zapewnienie warunków do egzystencji. Jałmużna stała się niejako ich obowiązkiem. Jednocześnie ostro zwalczano włóczęgostwo, dążono do oczyszczenia parafii z obcych żebraków ${ }^{71}$. Rozwój szpitalnictwa w Rzeczypospolitej przypada na drugą połowę XVII w., wówczas to kraj był zniszczony wojną północną. Sieć szpitali była jednak dość rzadka, w diecezji wileńskiej jeden szpital przypadał na $653 \mathrm{~km}^{2}$, a stan przytułków budził poważne zastrzeżenia. Szpitale tylko w minimalnym stopniu zaspokajały podstawowe potrzeby ludzi ubogich i chorych, tylko nieliczne szpitale zajmowały się leczeniem. Obowiązek udzielania pomocy potrzebującym spoczywał także na każdym klasztorze, parafii, bractwie i cechu, był praktykowany na dworach magnackich, szlacheckich,

\footnotetext{
67 S. Litak, Parafie w Rzeczypospolitej w XVI- XVIII wieku, Lublin 2004, s. 347.

68 Ibidem, s. 347.

69 J. Żmigrodzki, op. cit., s. 37.

70 Akty izdavaemye Wilenskoju Archeografičeskoju Kommissieju dla razbora drevnich aktov, Wilno 1870, t. 4, s. 194; Sapiehowie. Materiaty..., t. 2, s. 82; Sapiehowie. Materiały.., t. 3, s. 18.

71 S. Litak, Od Reformacji do Oświecenia. Kościót katolicki w Polsce nowożytnej, Lublin 1994, s. 200 .
} 
przez mieszczan ${ }^{72}$. Motywem zakładania szpitalnych przytułków była natomiast głęboko odczuwana idea chrześcijaństwa, niezależnie od tego, czy będzie to inicjatywa biskupa, zakonów czy ludzi świeckich, a także prestiż rodu, fundatorów. W związku z nowymi wyznacznikami potrydenckiego Kościoła katolickiego, fundacja szpitala była wymogiem dla zdobycia wizerunku dobrego chrześcijanina-katolika. Lew Sapieha: najpierw prawosławny, potem kalwinista, w końcu katolik, w kontekście swojej rosnącej pozycji w obrębie elit litewskich, jak i całej Rzeczypospolitej, musiał udowodnić, iż jego katolicyzm jest już dobrze ugruntowany. Wydaje się także, iż jego fundacje, również szpitalne, inspirowane były myślą o prestiżu jego synów. Działalność ojca miała ułatwić drogę kariery życiowej synom. Jego dzieło było kontynuowane przez potomków, którzy jedynie utrzymywali istniejące już szpitale, a tylko w nielicznych przypadkach inicjowali nowe. Na tym etapie badawczym bez odpowiedzi pozostają liczne pytania: jakie były fundacje szpitalne w następnych pokoleniach Sapiehów-spadkobierców Lwa i jego synów? W jaki sposób zmieniająca się sytuacja gospodarczo-polityczna w drugiej połowie XVII stulecia wpływała na stan sapieżyńskich fundacji? Czy w dobrach sapieżyńskich przechodzących w ręce innych rodów możnowładczych utrzymywane były zasady funkcjonowania szpitali? Była to wszak inwestycja niepodnosząca rentowności dóbr. Raczej należy określić ją, jako ,inwestycję w życie wieczne" przez sam akt miłosierdzia. Te i inne pytania wymagają dalszej, pogłębionej kwerendy źródłowej i porównania fundacji sapieżyńskich z innymi rodami magnackimi w Wielkim Księstwie Litewskim.

\section{Szkoły parafialne}

Początki zakładania przy kościołach szkół parafialnych sięgają epoki średniowiecza. Były one wówczas jednak nieliczne i z reguły zakładane przy kościołach w miastach. Szkoła parafialna była instytucją nierozerwalnie związaną z kościołem parafialnym. Miała uczyć i wychowywać, służyła przede wszystkim elementarnemu nauczaniu i wychowaniu w duchu katolickim ${ }^{73}$.

Jak wynika z badań Jerzego Ochmańskiego, w połowie XVI w. w diecezji wileńskiej było 30 szkół, co do których jest pewność, że istniały, a 54, co do istnienia których nie ma całkowitej pewności ${ }^{74}$. Jeżeli wierzyć relacji o stanie diecezji biskupa Benedykta Wojny (1600-1615) z 1605 r., która została oparta na wizytacji diecezji, to szkoły parafialne istniały prawie przy każdej

72 Idem, Parafie..., s. 359-360.

73 Idem, Od Reformacji do Oświecenia. Kościót katolicki w Polsce nowożytnej, Lublin 1994, s. 252.

74 J. Ochmański, Dawna Litwa. Studia historyczne, Olsztyn 1986, s. 116-119. 
parafii $^{75}$. Natomiast już w 1633 r. w trakcie wizytacji na 67 skontrolowanych parafii, szkoły istniały w 26. Dane co do pozostałych parafii są niekompletne lub w ogóle brak jest informacji ${ }^{76}$. Wydaje się, że tak liczny spadek szkół jest niemożliwy. Wykluczone, aby $\mathrm{w}$ tak nieodległym czasie tak radykalnie zmieniła się ich liczebność. Druga połowa XVII w. oraz przełom XVII i XVIII w., był to okres wojen szwedzkich i moskiewskich, a także wojny domowej na Litwie w początkach XVIII w., co nie sprzyjało rozwojowi szkół parafialnych ${ }^{77}$. Okres wojen i zniszczeń nie doprowadził jednak do całkowitego upadku szkół. Pojawiają się one zarówno w większych, jak i mniejszych ośrodkach parafialnych ${ }^{78}$. Kolejnym czynnikiem składającym się na funkcjonowanie szkoły był jej nauczyciel. Według badań E. Wiśniowskiego na określenie nauczyciela szkoły parafialnej używano określenia minister, minister eccleciae, minister scholae ${ }^{79}$. Jednocześnie dość często pojawiają się w źródłach termin bakałarz, choć bakałarz to także stopień akademicki. W okresie największego rozwoju szkolnictwa parafialnego, czyli w XVI w. i w połowie XVII w. liczba nauczycieli była większa, nauczyciele posiadali swoich zastępców-kantorów, a także pomocników. Małe szkoły parafialne miały zazwyczaj tylko jednego nauczyciela. Głównym składnikiem szkoły byli jej uczniowie, którzy w źródłach występują pod terminami pueri, iuvens, proles, scholares, lub także po polsku - uczniowie, dzieci. Szkoły miejskie były lepiej rozwinięte, posiadały większą liczbę uczniów, lepiej też opierały się wszelkim kryzysom. Natomiast w szkołach usytuowanych na wsiach liczba uczniów była mniejsza. Mogło to wynikać z faktu, iż ludność nie korzystała ze szkół parafialnych, a utrzymywano je tylko, jako pomoc w sprawowaniu liturgii ${ }^{80}$. Czas trwania nauki zależał od wielu czynników, m. in. od natężenia prac polowych. Nauka odbywała się głównie zimą bądź latem, w zależności od miejscowych zwyczajów.

Warto zadać pytanie, jaka była główna przyczyna podjęcia decyzji o zakładaniu przy kościołach szkół? Przypuszczać można, że na decyzję tę wpłynęły dwa zasadnicze czynniki. Po pierwsze fundatorowi przyświecał prawdopodobnie zamysł stworzenia szerszego dostępu do kapłaństwa młodym chłopcom z parafii, a także fakt, iż szkoła parafialna miała zadbać o praktyczne przygotowanie

75 Relationes status dioecesium in Magno Ducatu Lituanieae, t. 1: Dioecesium Vilnensis et Samogitiae. Pluribus adlaborantibus in unum redegit Paulus Rabikauskas, Romae 1971, s. 28.

76 Biblioteka Uniwersytetu Wileńskiego, F. 57.B53.40, Akta wizytacji z 1633 r.

77 J. Ochmański, Historia Litwy, Wrocław-Warszawa-Kraków 1990, s. 157-160.

78 J. Kurczewski, Biskupstwo wileńskie od jego założenia aż do dni obecnych, zawierające dzieje i prace biskupów i duchowieństwa diecezji wileńskiej oraz wykaz kościołów, klasztorów, szkót i zakładów dobroczynnych i społecznych, Wilno 1912, s. 276-277.

79 E. Wiśniowski, Uwagi na temat sieci szkót parafialnych $w$ Polsce na przełomie XVI/XVII w., [w:] Nauczanie $w$ dawnych wiekach. Edukacja w średniowieczu i u progu ery nowożytnej. Polska na tle Europy, pod red. W. Iwańczaka, K. Brachy, Kielce 1997, s. 14-20.

80 S. Litak, Parafie..., s. 311. 
chłopców do pomocy w sprawowaniu obrzędów liturgicznych. Przyczyny fundacji szkół związane były także z szeroko pojętymi przemianami społecznymi, z zapotrzebowaniem na tego typu placówki i funkcjami, jakie spełniały one w ówczesnym społeczeństwie. Zjawisko to w dużej mierze związane było decyzjami Soboru Trydenckiego, który zwrócił uwagę na konieczność podjęcia inicjatyw na polu edukacji społeczeństwa, w szczególności wiejskiego.

Jak wiadomo, Sapiehowie uchodzili za jednych z najhojniejszych pod względem fundacji. W związku z tym, iż sami dbali o odpowiedni poziom wykształcenia, podejmowali również starania zmierzające do edukacji najniższych warstw społeczeństwa. Pierwsze szkoły parafialne w Wielkim Księstwie Litewskim pojawiły się dopiero po 1387 r., gdy zaczęła powstawać sieć parafii. W diecezji wileńskiej jedne z pierwszych szkół pojawiły się w Obolcach oraz w Nowych Trokach ${ }^{81}$.

Szkoły fundowane przez Sapiehów powstawały kolejno w 1593 r. (Ikaźń), 1604 r. (Czereia, Lepl, Starosiele, Tołoczyn), 1608 r. (Słonim), 1626 r. (Hory). W odpowiedzi na protestantyzm, Lew Sapieha ufundował szkołe przy nowo powstającym kościele w Ikaźni ${ }^{82}$. Pierwotny fundusz z 1593 r. okazał się niewystarczający, ponieważ już kilka lat później, w 1596 r., Sapieha uzupełnił fundację kolejnymi nadaniami. Kościół w Ikaźni i Pohoście otrzymał dodatkowo wsie Milewicze i Sukielowicze wraz z poddanymi i ich powinnościami, a także myto targowe w mieście Ikaźni, z którego dochód roczny wynosił kop 7 groszy litewskich oraz dochody z karczem gorzałczanych ${ }^{83}$. Wśród wielu zadań spoczywających na plebanie, dodatkowo fundator nałożył obowiązek stałego mieszkania w parafii, utrzymywania mistrza i kantora znających język litewski ${ }^{84}$. Niezwykle istoty jest zapis dotyczący znajomości języka litewskiego przez nauczyciela bądź plebana, aby prości ludzie mogli zrozumieć Słowo Boże. Sapieha najwyraźniej znał i rozumiał potrzeby lokalnego społeczeństwa, skoro tylko w zapisie dotyczącym szkoły w Ikaźni i Pohoście pojawia się zapis zatrudniania nauczyciela bądź plebana znającego język litewski, którym na co dzień posługiwali się ludzie prości. Najwięcej, bo aż cztery szkoły, powstały w 1604 r. Mogło to być związane z postanowieniami synodu diecezji wileńskiej z 1602 r., który określał, aby

81 A. Pacevicius, Szkolnictwo, [w:] Kultura Wielkiego Księstwa Litewskiego, oprac. V. Alisauskas, L. Jovaisa, M. Paknys, E. Raila, Kraków 2006, s. 716.

82 B. Czart. 1777, s. 585-589, Fundusz Leona Sapiehy, 16 lipca 1593, Ikaźnia.

83 Ibidem, s. 614, Potwierdzenie i uzupełnienie przez Zygmunta III sapieżyńskich nadań dla Ikaźni i Pohostu, 28 maja 1596.

${ }^{84}$ Ibidem, s. 616, Potwierdzenie i uzupełnienie przez Zygmunta III sapieżyńskich nadań dla Ikaźni i Pohostu, 28 maja 1596: ...nie inakszego plebana prezentowali, jedno któryby tam przy tych kościołach sam ustawicznie mieszkat, y dla lepszego opatrzenia porzqdku kościoła wikarie chowat, $i$ dla ćwiczenia dzieci mistrze i kantory mieć byt powinien, także języka litewskiego , którego pospolicie tam ludzie prości nie umieja, albo sam pleban umiejętny, albo też wikariego dla przepowiadania Słowa Bożego i nauki ludzi prostych chowat. 
przy każdym kościele parafialnym była szkoła i nauczyciel o nienagannej opinii. Te same postanowienia zostały powtórzone na synodach w latach 1613, 1633 oraz w $1685^{85}$. Następnie z inicjatywy Sapiehy powstała szkoła w Czerei, która otrzymała własne uposażenie $\mathrm{w}$ postaci gruntów. Jednocześnie fundator zobowiązał plebana, aby zatrudniał bakałarza oraz kantora ${ }^{86}$. W tym samym roku 1604 r. Lew Sapieha wydał akt fundacyjny na kościól, szkołę i szpital w Leplu, miasteczku należącym do jego dóbr w województwie połockim, który został zatwierdzony przez Zygmunta III w 1606 r. ${ }^{87}$ Dochody z ziemi należącej do szkoły w Leplach miały służyć jako wynagrodzenie za pracę dla bakałarza, a w zamian za to fundator zobowiązał plebana do sprawowania opieki nad szkołą, utrzymywania bakałarza i kantora ${ }^{88}$. Posiadanie przez nauczycieli kawałka gruntu rolnego należało do często spotykanych elementów uposażenia. $\mathrm{Z}$ powodu bardzo fragmentarycznej bazy źródłowej nie można jednoznacznie stwierdzić, czy do uposażenia nauczyciela szkółki parafialnej, należały tylko grunty, czy może jeszcze dodatkowe uposażenia. Szkoła w Starosielu przy kościele katolickim pod wezwaniem Trójcy Przenajświętszej otrzymała plac i sad ${ }^{89}$.

Akcja związana $\mathrm{z}$ fundowaniem szkół parafialnych przy katolickich kościołach związana była z ożywieniem religijnym katolików, zagrożonych wpływami protestanckimi. Zrozumiano, że szkolnictwo i wychowanie młodzieży może odegrać dużą rolę w utrzymaniu wyznawców obrządku katolickiego w Kościele rzymskim. Utrzymywanie szkół parafialnych na terenach, gdzie warunki pracy były o wiele trudniejsze niż w Koronie, nie zawsze zachęcało do zakładania i prowadzenia szkół. Miasta, w których Sapieha ufundował szkoły, były niewielkie, a katolicy stanowili w nich mniejszość. Nie zawsze było to więc atrakcyjną ofertą dla nauczycieli wobec wielu problemów, jakie mogliby zastać w nowym miejscu pracy. Nowo powstające szkoły były o wiele trudniejsze do prowadzenia, trzeba było zbudować je od podstaw, zorganizować pomoce naukowe, przekonać lokalną ludność do posyłania dzieci do szkoły, a także nawiązać współpracę z plebanem parafii. Problemem mogło być też sprowadzenie i zatrzymanie nauczyciela w szkole parafialnej. Być może dlatego fundator, zdając sobie sprawę

\footnotetext{
85 A. Pacevicius, op. cit., s. 718.

86 Bibl. Czart. 1777, s. 679-681, Fundacja Lwa Sapiehy w Czerei, potwierdzona przez Zygmunta III, 6 sierpnia 1604 r.: ...na który kościót daje wiecznym i nieodzownym prawem zapisuje, naprzód plac, na którym zbudowany kościót z cmentarzem. Przy tym place na plebanię, na szkołę, na szpital $i$ na ogrody plebanowi, a na folwark włók pięć, w tymże miasteczku Czereia we trzech polach wedle ograniczenia $i$ opisania...

87 Ibidem, s. 682, Fundacja Lwa Sapiehy w Leplach z 1604 roku, potwierdzona przez Zygmunta III w roku 1606.

88 Ibidem.

89 Ibidem, s. 691-695, Potwierdzenie przez Zygmunta III w 1606 roku fundacji Lwa Sapiehy w Starosielu w powiecie orszańskim, z roku 1604.
} 
z tych trudności w wielu aktach fundacyjnych, zobowiązuje plebanów do utrzymywania bakałarza i kantora ${ }^{90}$. Powtarzający się niemal w każdym akcie fundacyjnym obowiązek utrzymywania bakałarza i kantora może również świadczyć o występowaniu przypadków zaniedbywania swoich powinności. Brak nauczyciela w parafii mógł także wynikać z niedostatecznego uposażenia parafii lub zubożenia pierwotnego uposażenia.

Interesujące jest umiejscowienie szkół parafialnych. Właściwie znajdowały się w miejscowościach należących do Sapiehów, głównie w powiecie orszańskim. Lew Sapieha w trakcie sprawowania godności starosty słonimskiego przyczynił się do powstania szkoły w tym mieście ${ }^{91}$. Ciekawie wygląda fundacja w Leplu, było to miasteczko nowo nabyte przez Lwa Sapiehę, w którym powstał kościół oraz szkoła. Majętność tę Sapieha wyłączył z dziedziczenia, przeznaczając ją dla klasztoru bernardynek w Wilnie, którego również był fundatorem oraz na kaplicę przy kościele Św. Stanisława w Wilnie ${ }^{92}$.

Na tym etapie badań nie można udzielić odpowiedzi na pytania, jakie było wykształcenie nauczycieli, jak wyglądało nauczanie, a także ile dzieci uczęszczało do szkółki. Przypuszczać można, że ówczesny nauczyciel musiał ukończyć przynajmniej szkołę parafialną. Do końca XVIII wieku do rzadkości należała obecność w wiejskiej szkole parafialnej nauczyciela z wyższym wykształceniem. Wiedza takiego nauczyciela musiała obejmować umiejętność pisania i czytania, początki łaciny, a ponadto znajomość śpiewu kościelnego i ministrantury. Zdarzały się również przypadki, że nauczyciele szkółek parafialnych mieli za sobą odbyty okres nauczania w szkołach katedralnych lub kolegiackich. Nie można również wysunąć przypuszczenia, że funkcje nauczyciela pełnił organista, kantor lub też zakrystian. Fragmentaryczne informacje na temat szkół fundowanych przez Sapiehów pozwalają wątpić w ich istnienie w drugiej połowie XVII stulecia. Prawdopodobnie luki w protokołach wizytacyjnych odnośnie istnienia szkoły wynikały z niewielkiego zainteresowania wizytatorów problematyką oświaty wiejskiej w parafiach, które wizytowali. Pomijanie przez wizytatorów informacji o funkcjonowaniu szkół parafialnych należy odnieść także do wieku XVIII.

90 Ibidem, s. 698, Potwierdzenie przez Zygmunta III fundacji Tołoczyna dokonanej przez Lwa Sapiehę. Podobne zapisy pojawiają się także w fundacjach dla szkół w Ikaźni, Pohoście, Czerei, Leplach, Starosielu, Słonimie, Dzięciole, Horach, Kossowie.

91 Ibidem, s. 726-729, Potwierdzenie przez Zygmunta III fundacji kościoła w Słonimie uczynionej przez Lwa Sapiehę, 5 lipca 1608 r.: ...Leo Sapieha kanclerz WXL, na on czas będąc starosta słonimskim, nowy kościót katolicki rzymski, w mieście naszym słonimskim na gruncie naszym kosztem swoim zbudowat, i ku temu kościołowi ogrodu zamkowego, na cmentarz, szkote, na domy kapłańskie, na szpital i ogrody wymierzyć rozkazat $i$ nadat, $w$ tych granicach leżqcego...

92 Ibidem, s. 682, Fundacja Lwa Sapiehy w Leplach z 1604 roku, potwierdzona przez Zygmunta III w roku 1606. 
Szczytowy rozwój szkolnictwa parafialnego przypada na koniec XVI w. i początek XVII w., którego głównymi propagatorami byli Kościół i magnaci. Kryzys szkolnictwa przypada na okres drugiej połowy XVII w. oraz w początkach XVIII w., gdy nastąpiła stagnacja gospodarcza. Ponadto średnia szlachta i część magnaterii nie była zainteresowana w dalszym kształceniu najniższych warstw społeczeństwa, a jeżeli już się decydowali wspierać szkolnictwo parafialne to tylko w ograniczonym zakresie. Wzrastające przywiązanie chłopa do ziemi powodowało, że nie widzieli oni korzyści z nauki. Coraz większe zainteresowanie wzbudzało szkolnictwo zakonne, zwłaszcza jezuickie. Bogactwo typologii obiektów sakralnych fundacji sapieżyńskich świadczy o ogromnym wkładzie Sapiehów w dzieło fundacji w Wielkim Księstwie Litewskim.

Wśród przedstawicieli rodu Sapiehów to właśnie Lew Sapieha był tym, który ufundował najwięcej obiektów sakralnych. Znaczna ilość fundacji znajdowała się w dobrach należących do Sapiehów. Wśród fundacji przeważały świątynie katolickie, poprzez które konwertyta, Lew Sapieha chciał pokazać swoją przynależność do katolicyzmu. Fundacje zapoczątkowane tuż po zmianie konfesji w 1586 r. miały ukazać go jako gorliwego katolika. Choć licznym fundacjom sapieżyńskim przyświecał, jako główny cel pomnożenie Chwały Bożej, to okazywane dobrodziejstwa świadczyły także o bogactwie i wpływach. Towarzyszyła również temu chęć pokazania swojej wielkości i poniesienie prestiżu. Na fundowanych świątyniach i pozostałych obiektach sakralnych fundator umieszczał swoje nazwisko, herb, portrety. Fundacje świątyń, zgromadzeń zakonnych, fundacje mszalne, altarii, szkół, szpitali, stanowiły jeden z wyznaczników prestiżu magnata, były elementem wyróżniającym go w danym środowisku. Pod płaszczyzną szeroko pojętej pobożności, fundacje umacniały wpływy Sapiehów na danym terytorium. Warto zauważyć, iż fundacje te były dokonywane na terenie zróżnicowanym wyznaniowo, przez co miały za zadanie również propagować idee wiary katolickiej, zwłaszcza wśród ludności protestanckiej, a także utrzymanie unii kościelnej. U podstaw fundacji leżały różne motywy, z jednej strony religijne, a $\mathrm{z}$ drugiej związane $\mathrm{z}$ prestiżem rodu. Choć $\mathrm{w}$ aktach fundacyjnych, zwłaszcza w testamentach, Sapiehowie akcentowali przede wszystkim motywy związane z religijnością, jako jedyne, które skłoniły do zapoczątkowania danej fundacji, to należy pamiętać, iż wiele inicjatyw fundacyjnych powstało, aby zaznaczyć i utrwalić znaczenie rodu. Fundacje szpitali, szkół oraz mszalne są nierozerwalnie związane z fundacjami kościołów i klasztorów, zajmują szczególne miejsce w historii, stanowią ważne źródło informacji dotyczących mentalności, codziennej kultury, wiary i sposobu życia ówczesnego możnowładztwa.

Niewątpliwie liczne i jakże bogate fundacje dokonane przez prezentowanych Sapiehów, głównie przez Lwa Sapiehę, świadczą nie tylko o ich religijności, ale również o hojności na cele sakralne. Duża liczba fundowanych obiektów sakralnych związana była zapewne z ówczesną sytuacją gospodarczą. Liczne dokonania fundatorskie Lwa Sapiehy i jego najmłodszego syna, Kazimierza Leona przynio- 
sły im opinię największych fundatorów w rodzie Sapiehów. Natomiast fundacje Jana Stanisława Sapiehy są nieliczne, gdyż nie wykazywał on aktywności na polu fundacji, co być może wynikało z jego słabego stanu zdrowia. Nie musiał on w takim stopniu, jak jego ojciec budować podstaw prestiżu. Potomkowie Lwa Sapiehy już w mniejszym stopniu podejmowali działania fundacyjne. Synowie Lwa Sapiehy, katolicy w drugim pokoleniu, nie musieli przez fundacje sakralne udowadniać swojej przynależności do Kościoła zachodniego. Ponadto fundacje sapieżyńskie to nie tylko inwestycja w życie wieczne, ale również wyraz ogromnych możliwości finansowych, jakie posiadał Lew Sapieha i jego potomkowie.

\section{A typology of the Sapieha sacral foundations in the Grand Duchy of Lithuania at the turn of the XVII century}

In the Sapieha family it was its main representative - Lew Sapieha, who was not only a recognized political activist but also a renowned founder. He founded numerous sacral objects - among them: parish churches, religious congregations, schools, hospitals and the Mass foundations. A conspicuous part of the founded objects was built on the Sapieha land. Lew Sapieha - originally a member of the Orthodox Church, then a Protestant and finally a Catholic - as a convert, was profoundly involved in the Catholic and Unite Churches activities.

Jan Stanisław Sapieha, Great Lithuanian Marshal, could not boast similar achievements. Despite having a large estate, which became even bigger after his marriage with Anna Scholastyka Chodkiewicz, the number of his foundations is not big.

It was Lew Sapieha's youngest son - Kazimierz Leon, who continued his father activity. Yet, it is to be stated that he focused on finishing his father's foundations rather than creating his own ones.

This weak engagement of Lew Sapieha's sons in social activities resulted form several factors, such as health problems (in the case of Jan Stanisław). It is not to be neglected that Lew Sapieha's sons were born as Catholics, and thus, did not have to prove they belonged to this denomination. Moreover, unlike their father, they were not bound to painstakingly build their careers and prestige.

The rich typology of the Sapieha sacral foundations reflects the family's great input into foundational activities in the Grand Duchy of Lithuania. 